\title{
Radioimmunoassay of Astroprotein (An Astrocyte-Specific Cerebroprotein) in Cerebrospinal Fluid and Its Clinical Significance
}

\author{
Takesada Mori, Kazuyoshi Morimoto, Toru HaYakawa, \\ Yukitaka Ushio, Heitaro Mogami and Kiyoshi Sekiguchi* \\ Department of Neurosurgery and Department of General Surgery, \\ Osaka University Medical School, Osaka, Japan. \\ Dinabot RI Laboratories*, Chiba, Japan.
}

\begin{abstract}
Summary
Using radioimmunoassay, astroprotein (an astrocyte-specific cerebroprotein) in cerebrospinal fluid (CSF) from 81 cases with intracranial diseases (60 brain tumors and 21 miscellaneous lesions) and four cases with non-intracranial diseases was measured. Astroprotein in CSF of cases with non-intracranial disease was generally below $25 \mathrm{ng} / \mathrm{ml}$. In contrast, 10 of 17 cases $(58.8 \%)$ with glioma, 10 of 43 patients $(23.3 \%)$ with brain tumors other than glioma and four of 21 patients $(19.0 \%)$ with miscellaneous intracranial diseases (including seven cases of intracranial aneurysm, four of meningitis, three of hydrocephalus, three of epilepsy and two of Parkinsonism) showed elevated astroprotein (up to $500 \mathrm{ng} / \mathrm{ml}$ or more) in CSF. The cystic fluid in glioblastoma usually contained remarkably large amounts of astroprotein.
\end{abstract}

Key words: Radioimmunoassay, astroprotein (an astrocyte-specific cerebroprotein), cerebrospinal fluid, glioma, immunological diagnosis.

\section{Introduction}

Bogoch (1966) reported a remarkable increase of an acidic cerebroprotein fraction, group $10 \mathrm{~B}$, in the brains of patients suffering from Tay-Sachs' disease and glioma. ${ }^{2)}$ Subsequently, immunofluorescence studies on human brain tumors were conducted by Mori, Mogami, Benda and Sweet $(1968)^{8)}$ and Benda, Mori and Sweet (1970), ${ }^{11}$ and they revealed that an unknown particular cerebroprotein of this group 10B was localized specifically in glial cells. Furthermore, Mori (1970) demonstrated that this particular cerebroprotein was localized specifically in astrocytes and named it "astroprotein". ${ }^{9,101} \mathrm{Re}$ cently, purification of this protein from human glioma tissue has been successfully conducted by

This paper was presented at the Thirty-fifth Annual Meeting of the Japan Neurosurgical Society, Maebashi, Gunma, October $21,1976$.

This study was supported in part by a grant-in-aid for cancer research from the Ministry of Health and Welfare, the Ministry of Education, Japan and Society against Cancer, Osaka. the authors using an immunoadsorbent procedure.

The purpose of this study was to measure astroprotein in cerebrospinal fluid (CSF) by radioimmunoassay, and to estimate its clinical significance for the diagnosis of brain tumors.

\section{Materials and Methods}

1) Preparation of monospecific anti-astroprotein serum: Minced human glioma tissues, which were obtained at surgery or autopsy, were homogenized with $0.005 M$ phosphate buffer ( $\mathrm{pH} 7.1)$ for 5 minutes at $4^{\circ} \mathrm{C}$ with a VirTis 45 homogenizer. The ratio of wet weight of tissue to volume of buffer was $1: 5(\mathrm{w} / \mathrm{v})$. The suspension was sonicated at $20 \mathrm{kc} / \mathrm{sec}, 150$ watts for 5 minutes then centrifuged at an average of 63,000 times gravity for 90 minutes at $4{ }^{\circ} \mathrm{C}$ (S-1 fraction). Saturated ammonium sulphate was added to the extract in order to obtain a $30 \%$ saturated solution. After 1 hour at $4 . \mathrm{C}$, the precipitate was sedimented by centrifugation 6,000 times gravity for 15 minutes at $4^{\circ} \mathrm{C}$. The sediment was resuspended in $5 \mathrm{ml}$ of 
$0.005 M$ phosphate buffer $(\mathrm{pH} 7.1)$ (S-2 fraction). The $\mathrm{S}-2$ fraction was prepared by immunoadsorbent column chromatography $(2 \times 10 \mathrm{~cm})$ of CNBr-Sepharose 4B (Pharmacia Fine Chemicals, Uppsala, Sweden) coupled with rabbit antinormal human plasma serum (S-3 fraction). Antiserum against astroprotein was produced by repeated intramuscular injections (five times) of rabbit with $2 \mathrm{ml}$ of S-3 fraction $(0.5 \mathrm{mg})$ emulsified in an equal volume of Freund's complete adjuvant (DIFCO Laboratories, U.S.A.) at intervals of 10 days. Ten days after the last injection the antiserum was prepared.

2) Specificity of the anti-astroprotein serum: The specificity of the anti-astroprotein serum was determined by the micro-Ouchterlony technique, immunoelectrophoresis and immunofluorescence studies.

3) Purification of astroprotein: Details of the procedure for the purification of astroprotein have been extensively described by Mori et al. ${ }^{13}$ The method involves immunoadsorbents of $\mathrm{CNBr}$-Sepharose 4B coupled with goat antiprotein serum and the separation of astroproteinantibody complexes with $8 \mathrm{M}$ urea $(\mathrm{pH} \mathrm{6.5)}$

4) Purity of astroprotein: The purity of the final astroprotein preparation was assessed by $7.5 \%$ polyacrylamide-gel electrophoresis and by immunodiffusion method with anti-astroprotein serum.

5) Iodination of astroprotein: Purified astroprotein was radiolabeled with ${ }^{125} I$ by the chloramine-T method. ${ }^{5}$ The following ingredients were mixed and incubated for 10 seconds at room temperature: $7 \mu 1 \mathrm{Na}^{125} \mathrm{I}(83.7 \mathrm{mCi} / \mathrm{ml}$ $0.1 \mathrm{~N} \mathrm{NaOH}$ ), $25 \mu \mathrm{l}$ chloramine- $\mathrm{T}(3 \mathrm{mg} / \mathrm{ml}$ solution in $0.005 \mathrm{M}$ phosphate buffer, $\mathrm{pH} \mathrm{7.1)}$ and $100 \mu \mathrm{l}$ astroprotein $(0.1 \mathrm{mg} / \mathrm{ml}$ solution in $0.005 M$ phosphate buffer, $\mathrm{pH} 7.1)$. Next, $50 \mu \mathrm{l}$ of sodium metabisulphate $(6 \mathrm{mg} / \mathrm{ml}$ solution in $0.005 \mathrm{M}$ phosphate buffer, $\mathrm{pH} 7.1$ ) were added, followed by $25 \mu \mathrm{l}$ potassium iodide $(50 \mathrm{mg} / \mathrm{ml}$ solution in $0.005 \mathrm{M}$ phosphate buffer, $\mathrm{pH} 7.1$ ). The ${ }^{125} \mathrm{I}$ iodinated astroprotein was separated from the reaction ingredients by Sephadex G-25 column chromatography $(1 \times 35 \mathrm{~cm})$.

${ }^{125} \mathrm{I}$-astroprotein used in the radioimmunoassay was diluted in $0.005 \mathrm{M}$ phosphate buffer (pH 7.1). The specific activity of ${ }^{125}$ I-astropro- tein was estimated to be approximately 35 $\mu \mathrm{Ci} / \mu \mathrm{g}$.

6) Radioimmunoassay procedure: A competitive protein binding assay between ${ }^{125} \mathrm{I}$ labeled astroprotein and unlabeled astroprotein for antibody binding sites was used to quantitate unknown concentrations of astroprotein in CSF, serum and cyst fluid of brain tumors. The radioimmunoassay of astroprotein was performed using the following protocol in the given order: $100 \mu \mathrm{l}$ sample or appropriate standards, $100 \mu 1^{125} \mathrm{I}$-labeled astroprotein and $100 \mu \mathrm{l}$ rabbit anti-astroprotein serum diluted $1: 10,000$ in $0.005 M$ phosphate buffer $(\mathrm{pH} \mathrm{7.1)}$ were thoroughly mixed and incubated for 30 hours at $4^{\circ} \mathrm{C}$. Following the first incubation, $100 \mu$ goat antirabbit gamma-globulin serum diluted $1: 15$ in $0.005 \mathrm{M}$ phosphate buffer ( $\mathrm{pH} 7.1$ ) plus $100 \mu \mathrm{l}$ of $1 \%$ normal rabbit serum were added, and incubated for 48 hours at $4^{\circ} \mathrm{C}$. After the second incubation, the mixture was centrifuged at 3,000 times gravity for 30 minutes at $4^{\circ} \mathrm{C}$. The supernatants were decanted and radioactivity was measured in an automatic gamma counter (Shimazu Corporation, Tokyo, Japan).

7) Astroprotein determination in CSF, sera and cyst fluid of brain tumors: CSF, sera and cyst fluid were collected and stored at $-60^{\circ} \mathrm{C}$ until assayed. Concentrations of astroprotein were determined by the double antibody design. CSF was obtained from 81 patients with clinical and/or histopathological diagnosis of: glioma (17 cases); brain tumor other than glioma (43 cases); and intracranial diseases other than brain tumor (21 cases). Control CSF was obtained from four patients without clinical or laboratory evidence of intracranial diseases. Serum was obtained from 85 patients: glioma 23 ; brain tumor other than glioma 47 ; intracranial disease other than brain tumor 11; and without intracranial disease 4. Cyst fluid in brain tumor was obtained from 10 patients at surgery: glioma 6 ; and craniopharyngioma 4 .

\section{Results}

1) Specificity of anti-astroprotein serum: The anti-astroprotein serum used in this study was monospecific by the micro-Ouchterlony technique and by immunoelectrophoresis. The antiserum failed to react in the micro-Ouchterlony 
plate with normal human plasma, but produced a single precipitin line with astroprotein.

With regard to immunoelectrophoresis, the anti-astroprotein serum reacted with a single constituent of astroprotein that had the electrophoretic mobility of a beta-globulin.

Furthermore, as the result of the immunofluorescence study of human brain tumors, antiastroprotein serum specifically illuminated brilliantly the cytoplasm of fibrillary, gemistocytic and pilocytic astrocytoma cells as well as of reactive astrocytes.

2) Purity of astroprotein: As a measure of purity of astroprotein. $7.5 \%$ polyacrylamide-gel electrophoresis was carried cut. The purified astroprotein prepared by the technique of Mori et al. gave a single intense line by $7.5 \%$ polyacrylamide-gel electrophoresis (Fig. la). With an antiserum directed against astroprotein, the immunoelectrophoresis pattern re-

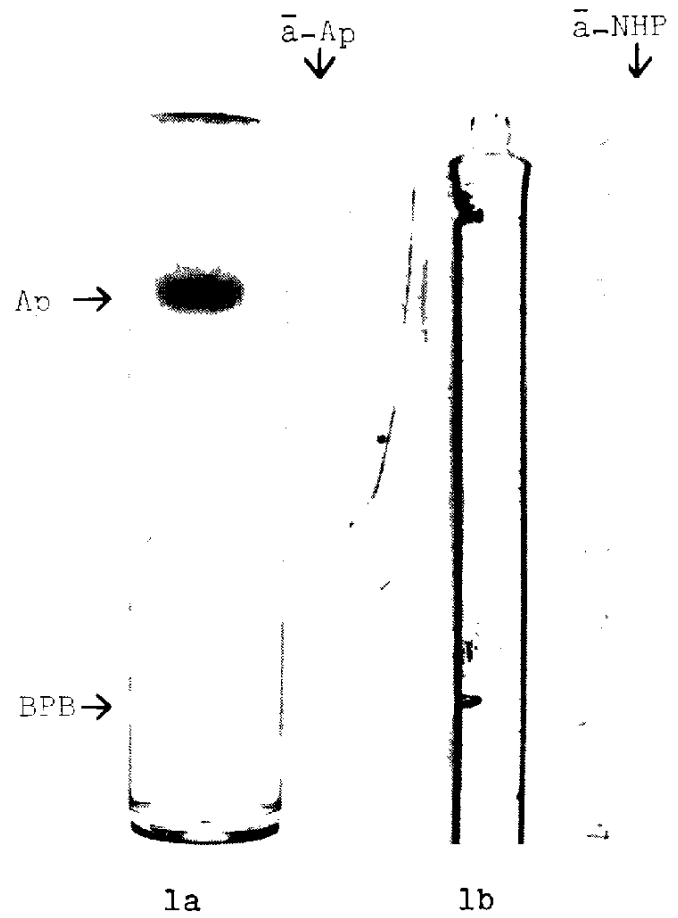

Fig. la $7.5^{\circ}$ "polyacrylamide-gel electrophoresis indicated a single line.

Fig. Ib Immunoelectrophoresis. Astroprotein (Ap) failed to react with anti-normal human plasma (āNHP), but there was a single precipitin line with antiast roprotein serum (a-Ap). BPB : brome phenol blue. vealed a single precipition line, but did not react with anti-normal human plasma (Fig. 1 b).

3) Radioimmunoassay of astroprotein: An antibody titration curve was prepared by reaction of ${ }^{125} \mathrm{I}$-astroprotein with serial dilutions of the anti-astroprotein serum (Fig. 2). A maximum specific binding of $72 \%$ of the ${ }^{125} \mathrm{I}$-astroprotein was obtained in the presence of antiastroprotein excess. A dilution of antiserum of $1: 10,000$ was used to obtain the standard coprecipitation-inhibition curve (Fig. 3). The

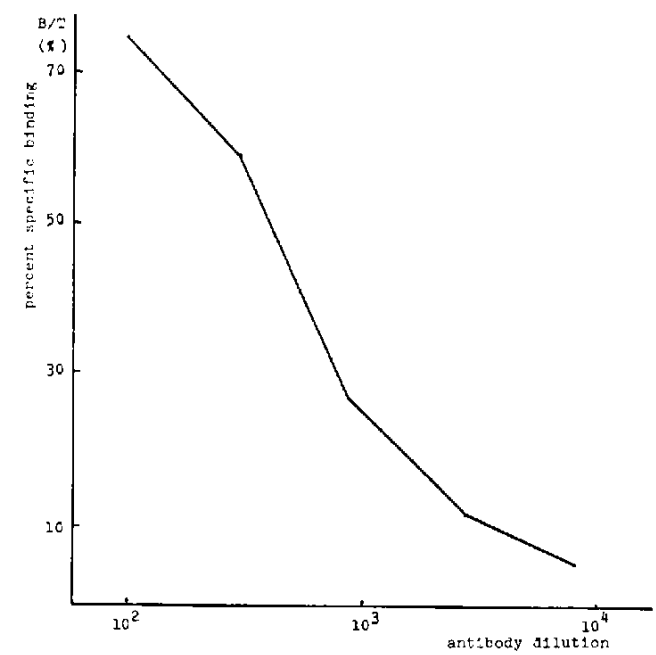

Fig. 2 Antibody titration curve of ${ }^{125}$ I-astroprotein incubated with serial dilution of anti-astroprotein serum.

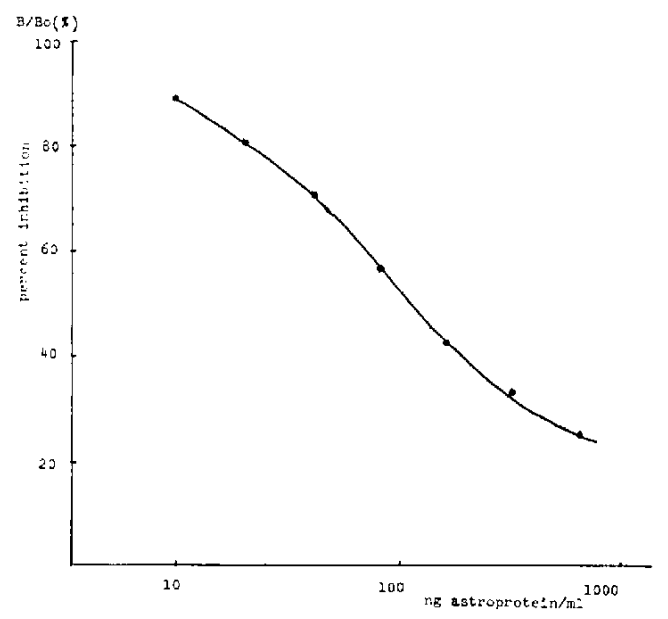

Fig. 3 Standard coprecipitation-inhibition curve for quantitation of astroprotein concentrations. 
standard inhibition curve demonstrated a linearity between 10 and $500 \mathrm{ng}$ (in $1 \mathrm{ml}$ ) of purified astroprotein solution.

4) Concentrations of astroprotein in CSF: The results of astroprotein determinations in CSF from patients are listed in Table 1, and represented graphically in Fig. 4. None of the individuals without intracranial disease demonstrated astroprotein values above $25 \mathrm{ng} / \mathrm{ml}$ of CSF. Eight of the nine CSF samples from the patients with glioblastoma clearly demonstrated elevated astroprotein values, and in three of them the value was elevated above $500 \mathrm{ng} / \mathrm{ml}$. One of the five patients with astrocytoma and one of the three patients with ependymoma showed elevated levels of 100 and $30 \mathrm{ng} / \mathrm{ml}$, respectively. Ten of the 43 patients with brain tumors other than glioma had an increased level of astroprotein in CSF but none were over $100 \mathrm{ng} / \mathrm{ml}$. Four of the 21 patients with intracranial diseases other than brain tumor also had elevated levels of astroprotein. Clinical diagnoses of these four patients were congenital hydrocephalus in two, genuine epilepsy in one and cryptococcal meningitis in the other.
5) Concentrations of astroprotein in human sera: The concentration of astroprotein in sera of the patients with various diseases were also determined. Increased amounts of astroprotein, ranging from 25 to $35 \mathrm{ng} / \mathrm{ml}$, were found in only four of the 85 patients; two patients with glioma, one with meningioma and the other with pituitary adenoma. The astroprotein levels in CSF of these four patients were all below $25 \mathrm{ng} / \mathrm{ml}$. Astroprotein could not be detected in sera obtained from one of the three patients showing remarkably elevated astroprotein in CSF (above $500 \mathrm{ng} / \mathrm{ml}$ ).

6) Concentrations of astroprotein in cyst fluid of brain tumors: Astroprotein levels in cyst fluid of gliomas (four glioblastoma, one astrocytoma and one ependymoma) were usually elevated above $500 \mathrm{ng} / \mathrm{ml}$. Two of the four cyst fluid samples of craniopharyngioma, showed elevated astroprotein values ranging from 97 to $100 \mathrm{ng} / \mathrm{ml}$, whereas the other two were below $25 \mathrm{ng} / \mathrm{ml}$.

7) Correlation between astroprotein levels and total protein levels in cerebrospinal fluid: Fortyseven patients were examined to find the re-

Table 1 Concentrations of astroprotein in cerebrospinal fluid and cyst fluid of brain tumors

\begin{tabular}{|c|c|c|c|c|c|c|}
\hline & \multicolumn{3}{|c|}{ CSF } & \multicolumn{3}{|c|}{ Cyst Fluid } \\
\hline & Cases & $25 \mathrm{ng}<$ & $500 \mathrm{ng}<$ & Cases & $25 \mathrm{ng}<$ & $500 \mathrm{ng}<$ \\
\hline Glioblastoma & 9 & 8 & 3 & 4 & 4 & 4 \\
\hline Astrocytoma & 5 & 1 & & 1 & 1 & 1 \\
\hline Ependymoma & 3 & 1 & & 1 & 1 & 1 \\
\hline Meningioma & 8 & 1 & & & & \\
\hline Pituitary adenoma & 8 & 1 & & & & \\
\hline Craniopharyngioma & 10 & 2 & & 4 & 2 & \\
\hline Pinealoma & 4 & 0 & & & & \\
\hline Neurinoma & 2 & 1 & & & & \\
\hline Sarcoma & 2 & 0 & & & & \\
\hline Chordoma & 1 & 0 & & & & \\
\hline Metastasis & 1 & 0 & & & & \\
\hline Teratoma & 1 & 1 & & & & \\
\hline Medulloblastoma & 3 & 2 & & & & \\
\hline Hemangioblastoma & 3 & 2 & & & & \\
\hline Aneurysm & 7 & 0 & & & & \\
\hline Parkinsonism & 2 & 0 & & & & \\
\hline Head injury & 2 & 0 & & & & \\
\hline Hydrocephalus & 3 & 2 & & & & \\
\hline Epilepsy & 3 & 1 & & & & \\
\hline Meningitis & 4 & 1 & & & & \\
\hline Non-intracranial disease & 4 & 0 & & & & \\
\hline
\end{tabular}




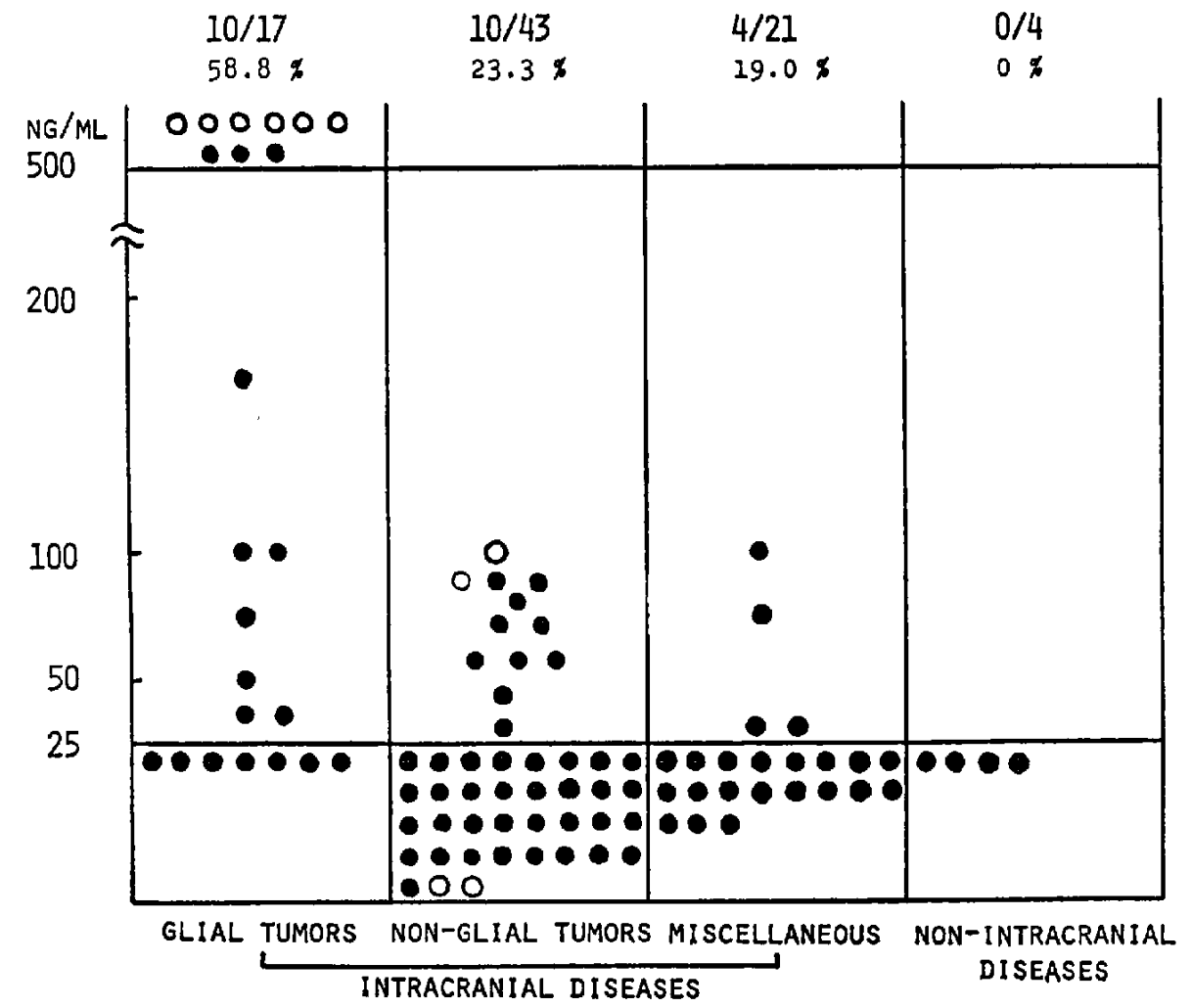

Fig. 4 Astroprotein levels measured in patients with various clinical disorders. Data from Table 1. solid point : cerebrospinal fluid, open point: cyst fluid of brain tumors.

lationship between their astroprotein levels and total protein levels in cerebrospinal fluid. As shown in Fig. 5, there was a positive correlation between them in glial tumors (p. $<0.05$ ), but not in the other two groups.

\section{Discussion}

The investigation of brain-specific proteins has recently advanced rapidly, and several kinds of protein including encephalitogenic factor (Kies, $1955)^{6)}$ and S-100 protein (Moore, 1965) ${ }^{7}$ have been described. Although the encephalitogenic protein has been identified to be a myelin protein, the tissue distribution of S-100 protein has not yet been definitely elucidated.

In contrast, astroprotein is detectable only in the cytoplasm of fibrillary astrocytes which are
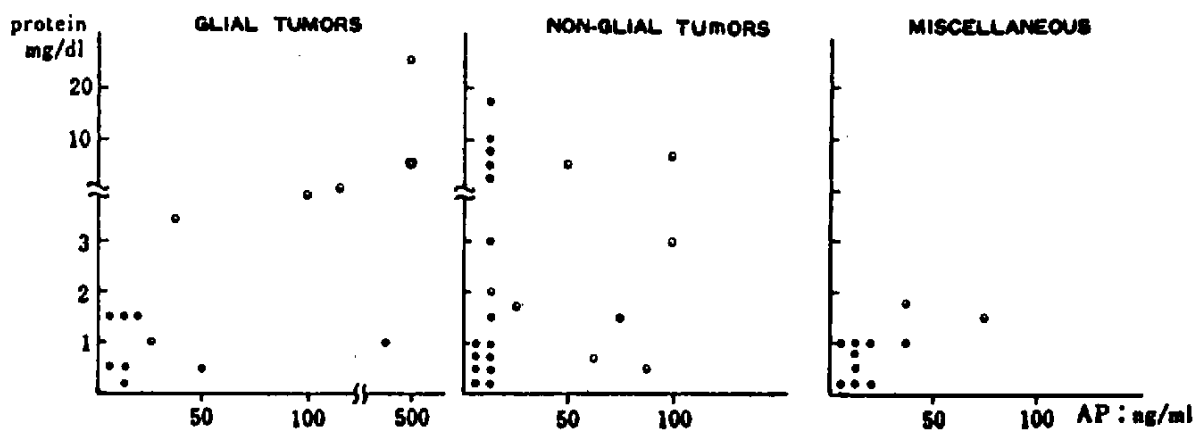

Fig. 5 Correlation between astroprotein levels and total protein levels in cerebrospinal fluid. 
distributed mainly in the white matter of normal brains of man, rat and mouse. Astroprotein was the first protein found to be specific for astrocytes. Astrocyte specific proteins were later extracted and isolated by Eng et al. from brain tissues with marked gliosis such as those with multiple sclerosis and hydrocephalus. ${ }^{3.41}$ They were referred to as glial fibrillary acidic proteins and were shown to be identical antigenic substances by gel diffusion, immunoelectrophoresis and immunofluorescence studies. Astroprotein and glial fibrillary acidic proteins are simple proteins with a molecular weight of approximately 43,000 . They have an electrophoretic mobility identical with that of $\beta$-globin and are presumed to be components of glial filaments based on Bodian staining and electron microscopy. ${ }^{11}$

Astroprotein could be eluted under acidic conditions from a column of DEAE-cellulose or DEAE-Sephadex A-25 and fractionated by gel filtration using a Sephadex G200 column. However, it was difficult to obtain a highly purified preparation of astroprotein. The preparation of glial fibrillary acidic proteins was shown to be contaminated with several proteins as examined by polyacrylamide electrophoresis.

We have made attempts to obtain pure preparations of astroprotein, and were successful in purifying it to homogeneity by a procedure including $30 \%$ ammonium sulfate fractionation, affinity column chromatography using antiastroprotein serum and DEAE-Sephadex A-25 column chromatography. Radioimmunoassay according to a double antibody method was developed. ${ }^{12)}$

According to observations by immunofluorescence study using anti-astroprotein serum, astroprotein is abundant in gemistocytic astrocytoma cells and fibrillary astrocytoma cells with long processes which have high cytoplasm/ nucleus ratios, whereas it is less abundant in glioblastoma cells with low cytoplasm/nucleus ratios. In contrast, astroprotein in CSF is detectable in larger quantities and more frequently in glioblastoma cells. This is presumably due to the fact that glioblastoma cells are more proliferative and are necrotized more easily than astrocytome cells, which are less malignant.

Astroprotein was also detected in CSF of some cases of brain tumor other than glioma and in CSF of other intracranial diseases in addition to tumors. In all these cases astroprotein was not detectable in amounts as large as in glioblastoma. Its occurrences seem to be attributed to the gliosis, i.e., the proliferation of reactive astrocytes as a secondary change.

Astroprotein concentration in the cyst fluid of glioblastoma and astrocytoma (six cases) was always higher than $500 \mathrm{ng} / \mathrm{ml}$, while such a high astroprotein concentration was not observed in brain tumors other than glioma. In the former cases astroprotein was derived from tumor cells, whereas its production was attributable to gliosis in the latter cases.

The increase in protein content in CSF of brain tumor patients has long been known and utilized in the clinical diagnosis of brain tumors. This increase in protein content is attributable mainly to the exudation of serum protein, and is not specific to brain tumors. On the other hand, astroprotein is hardly detected in normal blood and CSF (less than $25 \mathrm{ng} / \mathrm{ml}$ ). The increase in the astroprotein content in CSF strongly suggests the occurrence of glioma or gliosis, thereby being useful in clinical diagnosis. Especially when the astroprotein concentration is higher than 500 $\mathrm{ng} / \mathrm{ml}$, there is a very high probability of glioblastoma.

Although blood is more easily available and more useful than CSF as a sample for clinical tests, the astroprotein in serum remained at a normal level in many cases with high astroprotein content in CSF. There was no exudation of astroprotein into blood when isotope-labeled astroprotein was injected into the spinal fluid space of normal rabbits and it followed the change of astroprotein content in blood (unpublished experiment).

\section{References}

1) Benda, P., Mori, T. and Sweet, W. H.: Demonstration of an astrocyte-specific cerebroprotein by an immunofluorescence study of human brain tumors. J. Neurosurg. 33:281-286, 1970.

2) Bogoch, S. and Belval, P.: Brain proteins in the sphingolipidosis Tay-Sachs' disease protein. In "Inborn Disorders of Sphingolipid Metabolism". Aronson, S. and Volk, B. W. (Eds.) Pergamon Press, New York, pp. 273-278, 1966.

3) Bignami, A., Eng, L. F., Dahl, D.. and Uyeda, C. $T$. : Localization of the glial fibillary acidic protein in astrocytes by immunofluorescence. Brain Research 43: 429-435, 1972. 
4) Eng, L. F., Vanderhaeghan, J. J., Bignami, A. and Gerstle, B.: An acidic protein isolated from fibrous astrocyte. Brain Research 28: 351-354, 1971.

5) Hunter, W. M. and Greenwood, F. C. : Preparation of iodine-131 labelled human growth hormone of the high specific activity. Nature 194: $495-499,1962$.

6) Kies, M. W., Alvord, E. C. Jr., and Roboz, E. : Production of experimental allergic encephalomyelitis in guinea pigs with fractions isolated from bovine spinal cord and killed tubercle bacilli. Nature 182: 104 105, 1958.

7) Moore, B. and McGregor, D.: Chromatographic and electrophoretic fractionation of soluble proteins of brain and liver. J. Biol. Chem. 240: 1647-1653, 1965.

8) Mori, T., Mogami, H., Benda, P. and Sweet, W. H. : An astrocyte-specific cerebroprotein in normal brain and in human glioma. Neurologia medico-chirurgica 10: 103-104, 1968.

9) Mori, T.: Studies on astrocyte-specific antigen (astroprotein) Neurochemistry (Tokyo). 9: 75-78, 1970.

10) Mori, T. and Morimoto, K.: Astroprotein, an astrocyte-specific corebroprotein, in normal brain and glioma. Fourth International Meeting of the International Society for Neurochemistry Tokyo, (Abstracts pp. 174) 1973.

11) Mori, T. and Morimoto, K.: Studies on the identity of astroprotein (Mori) and glial fibrillary acidic protein (Eng). Igaku-no-ayumi 92: 16-17, 1975.

12) Mori, T., Morimoto, K., Ushio, Y., Hayakawa, T. and Mogami, H.: Radioimmunoassay of astroprotein (an astrocyte-specific cerebroprotein) in cerebrospinal fluid from patients with glioma. A preliminary study. Neurologia medico-chirurgica 15:23-25, 1975.

13) Mori. T., Morimoto, K. and Sekiguchi, K.: Purification of astroprotein (an astrocytespecific cerebroprotein) by immunoadsorbents of Sepharose 4B coupled with anti-astroprotein. (in preparation) 1977. 